\title{
Well Being till to the Age about 90 Year of Clients
}

\author{
*Antonín Cuc \\ The international expert in occupational Health and Safety, Czech Technical University, Europe
}

Submission: July 31, 2017; Published: August 02, 2017

*Corresponding author: Antonín Cuc, The international expert in occupational Health and Safety, Czech Technical University, Na Míčánkách 435/1,101 00 Prague 10, Czech Republic, Europe, Email: betruea@gmail.com

\section{Opinion}

There are a serious problem as in multidisciplinary understanding "to keep most of number of Citizens for all duration their lives in perfect mental and physical conditions", it means to motivate the behavior of People in limits racionality, with minimize private risks in their workplaces, clever nutrition regimes, perfect physical and mental conditions in their jobs, in well feeling in their Families, with well being in social atmosphere, with perfect prevency all serious private Health complications, stressing, etc. Then there are a perfect hopenning to keep motivation to live to geriatric Ages with minimum Health complication with polytraumatic diseases and asking the risky surgeries, complication with high blood pressure, arrhythmic Heart functions. Many patients are heavy injuring after Strokes, Heart infarcts, total Arthroplasty, heavy Diabetes Mellitus, blood Circulation, etc. Those Health problems for patients over 67 years we could identify in the independent random Samples with number in Dimension about 650 entities from Clients in Hospital nets in every State from OECD.

I am a Cybernetic about 72 year old, perfect educated in occupational risk, Health and Safety, including Medical Devices. The Physicians are lack of scientic arguments against me scientic Imagine about perfect functional working Channel with Complex Health and Social Care for the Citizens with Age over 67 years. When I am observing the various groups of Clients over Age 67 in Intensive Rehabilitation Institutes in Czech Republic - I could see for every Clients typical combination of a few typical heavy health complication summarized nearly by each individual Patient in some combinations - but the Physicians are extremely with medical specialization, there are nearly excluded to obtain the perfect Health integral medical support.

When I have got the first phases of the necrosis my femoral Head, my Orthopaed sent me on RTG Imaging my hips - but there were the false decision making - because the first Phases of necrosis femoral Head it is possible to diagnose only with taking the Magnetic resonation only - and there are not adequated Total Arthroplasty but nonsurgical treatments. I have studied this problem on Encyclopedic Human Orthopady, but no Physician in Orthopedic respects my patient education, experiences and my private suggestion of Diagnostic way. This is so as the reason, why in next 5 weeks my left hip-joint was full destructured - and My Orthopaed could realize total Arthroplasty - nearly needless and with more patient risks - because it is most financial profit for the Hospital Clinics from Health Assurance - and so for private income and prestige of my Orthopaed.

I am sure - the nonsurgical diagnoses and treatments are known in this necrosis femoral Head in other Orthopaedic Clinics in Medical Faculty with orthopedic research, but there are never accepting such progressive safety medical processing in "Productive Orthopady Clinics". The most progressive surgeries are such, where we could taken perfect timing regular Diagnostic methods and most safety Treatments with the hopening of patient for long being perfect locomotion and mental Status, without in forced total Anesthesia with danger for high mental Head functions, without risk by surgery to obtain the probable post operational infects in the long trajectories of scalpel, with more spent days after surgeries in Hospital care, post operational in forced physiatrist rehabilitation in RHB Clinics, with in forced probable worse loco motional standard, etc.

I have just 3 surgeries THA on the both my legs, but never it was for me the most clever medical Decision making. The Orthopaed began the surgeries on the right leg without mandatory Clinic individual Plan of surgery - he ignored the preliminary radiologic imaging my hips -there were described explicit the dysplastic declination of my femoral neck - despite such medical fatal technical orthopadic mistakes, my "Fausse route stem" was described against the criminal anthropology tracing - as postoperative happen patient fallen - despite there are full excluded with technical evidences preliminary and postoperative RTG Images of hips. The Knowing Institute - The Central Army Hospital Prague was created the false Medical Court Message with resulting "Whole processing was in limits Leger artis by the Czech habits", despite I am just preliminary needless dying on consequents. 
There are no enlightenment and prevency to repeat the same mistakes about absolute duties for Providers of care so as for Orthopedic staff by technician requirements of international Regulations for Orthopaedic Implanting by the Directive 93/42/EEC Medical Devices! There are lack of knowledge's in legsl conditions for Orthopaedic workplaces, for Orthopaedic processing by the Producer in voids, there are illegal to assembly the set of Implants contrary in forced technical firm regulations for perfect safety functions for planning time of patient usage! Each medical hypothesis are full false, when there are some supposing contrary Biomechanics, Geometry's $3 \mathrm{D}$, legal technical conditions by Laws, contrary firm installing measurement conditions, etc.

When you are taken the random Sample of Patients in Age over 67 in Dimension about 1200 Clients in the like hood Hospital nets, you could defined hundreds exact technical and so statistic conditions to prevent the Mass repeating the dangerous mortal medical mistakes in Orthopedic Diagnostics and Treatments in daily workflow. By the decision medical making should be keep regards so as respects to patient experiences and knowledges for example I am well educated Cybernetic for minimize risks by similar repeated decision making, but just I am needless dying too after many trivial repeated needless medical technical mistakes in implanting processing! There was criminal Act against me with agreement the Judge, with agreement the Criminal Policy of Czech Republic, with agreement of States Attorney's Office Czech Republic. You should be more carefully for your private Health and so as for your Human Rights for your Healthy, for the justified Court processing, for your justified Criminal evidences. It was impossible for me in Czech Justinian and Czech forensic Medicine, in Czech Orthopedic!

\section{Your next submission with Juniper Publishers will reach you the below assets}

- Quality Editorial service

- Swift Peer Review

- Reprints availability

- E-prints Service

- Manuscript Podcast for convenient understanding

- Global attainment for your research

- Manuscript accessibility in different formats ( Pdf, E-pub, Full Text, Audio)

- Unceasing customer service

Track the below URL for one-step submission https://juniperpublishers.com/online-submission.php 